\title{
Monitoring of the Contents of Manganese, Zinc, and Copper in Soils and Plants of the Central Chernozemic Region of Russia
}

\author{
S. V. Lukin ${ }^{a, *}$ and D. V. Zhuikov ${ }^{b}$ \\ ${ }^{a}$ Belgorod Center for Agrochemical Service, ul. Shchorsa 8, Belgorod, 308027 Russia \\ ${ }^{b}$ Belgorod State National Research University, ul. Pobedy 85, Belgorod, 308015 Russia \\ *e-mail: serg.lukin2010@yandex.ru
}

Received April 3, 2020; revised April 21, 2020; accepted May 27, 2020

\begin{abstract}
The paper discusses the data obtained in 2015-2018 by the State agrochemical monitoring of soils in Belgorod oblast. The research revealed that organic fertilizers are the main source of microelements entering phytocenoses. They are responsible for $79.2 \%$ manganese, $87.3 \%$ zinc and $84.2 \%$ copper of their total amount introduced with fertilizers and ameliorants. The Ap horizon of the ordinary chernozem (Haplic Chernozem) in the steppe zone contains $1.15,1.18$, and 1.14 times more manganese, zinc, and copper, respectively, than the typical chernozem (Haplic Chernozem) in the forest-steppe zone. The studied microelements show the biophylic accumulation in the arable layer. The average total content of manganese, zinc, and copper in the Ap horizon was higher than that in $\mathrm{C}_{\mathrm{Ca}}$ horizon in $1.49,1.17$, and 1.22 times, respectively, in the typical chernozem; and 1.42, 1.22, and 1.16 times in the ordinary chernozem, respectively. The results of continuous monitoring proved that $38.6 ; 98.7$, and $98.2 \%$ of the studied arable soils manifest a low supply with manganese, zinc, and copper, respectively. The highest content of manganese was found in grain $(1053 \mathrm{mg} / \mathrm{kg})$ and straw $(841 \mathrm{mg} / \mathrm{kg})$ of white lupine; that of zinc $(43.5 \mathrm{mg} / \mathrm{kg})$, in the grain of the same crop; and the maximal amount of copper was found in the soybean grain $(10.5 \mathrm{mg} / \mathrm{kg})$. The lowest accumulation of manganese $(9.22 \mathrm{mg} / \mathrm{kg})$ and zinc $(26.45 \mathrm{mg} / \mathrm{kg})$ is typical for pea grains, and that of copper, for winter wheat grains $(3.60 \mathrm{mg} / \mathrm{kg})$. The concentration of microelements was higher in grains than in straw of winter wheat, soybean and white lupine; whereas the inverse relationship was found for pea plants.
\end{abstract}

Keywords: chernozem, biological absorption coefficient, total content, fertilizers, ameliorants, the mobile compounds

DOI: $10.1134 / \mathrm{S} 1064229321010099$

\section{INTRODUCTION}

The modern farming considers the deficit in mobile compounds of the most important microelements in arable soils in many Russian regions as one of the reasons decreasing the crop yield and worsening the quality of many agricultural products [17, 18, 25].

Microelements perform a broad spectrum of biochemical functions in plants, most of them being related to activating various enzymes. Manganese activates ferments participating in phosphorylation and RNA synthesis. On its deficit, the synthesis of organic substances is disturbed in plants and the content of chlorophyll is reduced, which promotes chlorosis. Zinc activates more than 300 enzymes, which influence the metabolism of carbohydrates, phosphates, proteins, as well as the formation of growth hormones and DNA. The deficit in this element causes the formation of small asymmetrical leaves, small size of plants, and chlorosis in leaves' material between veins. A considerable shortage in zinc retards the formation of chlorophyll and saccharose. Copper participates in redox processes, photosynthesis, as well as carbohy- drate and protein exchange. Due to this element, the cultivated plants resist better to fungal and bacterial diseases, their standing stability increases, as well as resistance to droughts and frosts. Copper deficit violates the root system development, and slows down the plant growth [3, 30, 31, 34].

Since the atomic mass of the studied microelements exceeds 40 a.u., they are often referred to as "heavy metals"; and upon their high content in soil, they may become toxic for plants, being accumulated in products in concentrations dangerous for warmblooded beings. According to its toxicity, zinc is classified as element of first hazard class, whereas copper and manganese are referred to the second and third classes, respectively.

For standardizing the total content of zinc and copper, approximately permissible concentrations (APC) are used most often, which are equal to 220 and $132 \mathrm{mg} / \mathrm{kg}$, respectively, for loamy and clayey soils with $\mathrm{pH}>5.5$ [5]. For all soils, irrespectively of their texture and acidity, the maximal permissible concentration (MPC) of total manganese is accepted at $1500 \mathrm{mg} / \mathrm{kg}$. 
Table 1. Average content of organic matter and $\mathrm{pH}_{\mathrm{H}_{2} \mathrm{O}}$ in soil profiles

\begin{tabular}{|c|c|c|c|c|c|c|}
\hline \multirow{2}{*}{ Index } & \multicolumn{6}{|c|}{ Genetic horizon } \\
\hline & Ap & A & $\mathrm{AB}$ & $\mathrm{B}_{\mathrm{Ca}}$ & $\mathrm{BC}_{\mathrm{Ca}}$ & $\mathrm{C}_{\mathrm{Ca}}$ \\
\hline \multicolumn{7}{|c|}{ Typical chernozem } \\
\hline Average thickness of horizon, $\mathrm{cm}$ & $0-25$ & $26-36$ & $37-90$ & $91-111$ & $112-134$ & $>135$ \\
\hline Organic matter, $\%$ & 5.6 & 5.0 & 3.6 & 2.1 & 1.3 & 1.0 \\
\hline $\mathrm{pH}_{\mathrm{H}_{2} \mathrm{O}}$ & 6.7 & 6.9 & 7.5 & 8.0 & 8.1 & 8.1 \\
\hline \multicolumn{7}{|c|}{ Ordinary chernozem } \\
\hline Average thickness of horizon, $\mathrm{cm}$ & $0-25$ & $26-43$ & $44-72$ & $73-90$ & $91-124$ & $>125$ \\
\hline Organic matter, $\%$ & 5.2 & 4.8 & 4.1 & 2.9 & 1.9 & 1.6 \\
\hline $\mathrm{pH}_{\mathrm{H}_{2} \mathrm{O}}$ & 7.8 & 7.9 & 7.9 & 8.1 & 8.3 & 8.3 \\
\hline
\end{tabular}

According to the Russian norms, MPC for mobile compounds (extractable by ammonium acetate buffer with $\mathrm{pH}$ 4.8) of manganese, zinc, and copper are equal to 140,23 , and $3 \mathrm{mg} / \mathrm{kg}$, respectively [4]. In the current legislation, the maximal permissible levels (MPL) of zinc and copper in forage for cattle are taken as 50 and $30 \mathrm{mg} / \mathrm{kg}$, respectively, (in grain, as well as in raw and fresh forage) [2]. The content of manganese is not standardized in plant products used as forage. In food products, the content of manganese, zinc and copper is not regulated [22].

Depending on soil-climatic and geochemical specifics of the region, the total content and concentration of mobile forms of microelements vary significantly. Therefore, in accordance with the agroecological monitoring program, the Russian agrochemical survey carries out the recurrent continuous monitoring of agricultural soils for the content of mobile compounds of manganese, zinc, and copper. In addition, within the framework of local monitoring, the total content of these microelements is studied in soils and agricultural products. Proceeding from the analysis of this information, the scientifically grounded recommendations are given on the application of microfertilizers in modern agrotechnologies [9].

The present research was aimed at the investigation of regularities of microelement distribution $(\mathrm{Mn}, \mathrm{Zn}$, and $\mathrm{Cu}$ ) in soils and their accumulation in plants in the southwestern part of the Central Chernozemic region.

\section{OBJECTS AND METHODS}

The studies were performed in Belgorod oblast included in the Central Chernozemic region. In the forest-steppe zone, the soil cover of the cropland comprises typical chernozems (Haplic Chernozems) (44.8\%) and leached chernozems (Luvic Chernozems) (25.7\%); whereas in the steppe zone, it is composed of ordinary chernozems (Haplic Chernozems) $(1.0 \%$ of the total tillage area). The share of eroded tillage is equal to $47.9 \%$ in this oblast $[23,24]$. In 2015-2018, the total area under crop amounted to 1428.5 thousand ha on average [21].

The data of continuous agrochemical survey of plow soils were used in this study. In the survey, one united soil sample consisting of 20-40 point samples was taken from the arable $(0-25 \mathrm{~cm})$ soil horizon within the area of 20 ha.

To reveal the geographical regularities in the distribution of elements, 22 profiles of typical heavy loamy chernozem in the Middle Russian forest-steppe province and 22 profiles of typical light loamy chernozem in the Middle Russian province of steppe chernozems were studied. Data on the average thickness of soil horizons, organic matter content, and $\mathrm{pH}_{\mathrm{H}_{2} \mathrm{O}}$ values are listed in Table 1.

Chemical analyses were conducted in a certified laboratory of the Belgorod Center for Agrochemical Service according to routine procedures [13]. The total content of elements (the extracting agent $5 \mathrm{M} \mathrm{HNO}_{3}$ ) and the concentration of their mobile compounds in soil, extractable with ammonium acetate buffer (AAB) solution with $\mathrm{pH} 4.8$ was determined by atomic emission spectroscopy. Plants were sampled in the foreststeppe zone of the Belgorod oblast. The following crops were analyzed: winter wheat, soybeans, peas, clover, sainfoins, alfalfa, and meadow mixed herbs (22 samples of each plant species), as well as 20 samples of white lupine.

The statistical processing of the results obtained included the calculation of average values $(\bar{x})$, maximal and minimal (lim) concentrations of elements, confidence intervals for average values $\left(\bar{x} \pm t_{05} s \bar{x}\right)$, and variation coefficients $(V, \%)$.

To reveal the absorption selectivity of chemical elements by plants, the biological absorption coefficient (BAC) was used, which is found by dividing the amount of elements in the plant ash by the total content of the element in soil. 
Table 2. Variation and statistic indices of microelement content in organic fertilizers and defecate, $\mathrm{mg} / \mathrm{kg}$ of fertilizer (defecate)

\begin{tabular}{|c|c|c|c|c|}
\hline Elements & $n$ & $\bar{x} \pm t_{05} s \bar{x}$ & $\lim$ & $V, \%$ \\
\hline \multicolumn{5}{|c|}{ Straw and litter compost (56\% dry matter) } \\
\hline $\mathrm{Mn}$ & 25 & $159 \pm 21.0$ & $66-257$ & 32.6 \\
\hline $\mathrm{Zn}$ & 25 & $300 \pm 42.1$ & $139-451$ & 34.7 \\
\hline $\mathrm{Cu}$ & 25 & $181 \pm 22.7$ & $50.8-259$ & 31.0 \\
\hline \multicolumn{5}{|c|}{ Cattle manure (25\% dry matter) } \\
\hline Mn & 32 & $48.0 \pm 5.32$ & $17.4-88.4$ & 30.8 \\
\hline $\mathrm{Zn}$ & 32 & $20.0 \pm 2.44$ & $11.5-37.4$ & 33.8 \\
\hline $\mathrm{Cu}$ & 32 & $5.65 \pm 0.73$ & $3.66-11.6$ & 36.0 \\
\hline \multicolumn{5}{|c|}{ Manure sewage (2.22\% dry matter) } \\
\hline Mn & 26 & $3.97 \pm 0.59$ & $1.13-7.08$ & 36.7 \\
\hline $\mathrm{Zn}$ & 26 & $53.3 \pm 7.77$ & $22.7-88.9$ & 36.1 \\
\hline $\mathrm{Cu}$ & 26 & $9.18 \pm 1.40$ & $4.20-16.9$ & 37.7 \\
\hline \multicolumn{5}{|c|}{ Defecate (87\% dry matter) } \\
\hline $\mathrm{Mn}$ & 20 & $185 \pm 26.9$ & $97.4-268$ & 29.3 \\
\hline $\mathrm{Zn}$ & 20 & $43.8 \pm 7.54$ & $16.6-62.7$ & 34.6 \\
\hline $\mathrm{Cu}$ & 20 & $13.7 \pm 2.04$ & $7.53-20.7$ & 30.0 \\
\hline
\end{tabular}

\section{RESULTS AND DISCUSSION}

Sources of microelements entering soil. The soilforming materials are the main natural source of microelements in soils [14]. Emissions from nonferrous metallurgic enterprises and heat power plants, sewage water, fertilizers and ameliorants are the main anthropogenic sources of microelement ingress to agrocenoses. In the past century, copper sulfate widely used as a fungicide was an important source of copper in soils of perennial plantations. Near ferroalloy production enterprises and mines, the total content of manganese, zinc, and copper reaches 4600, 1690, and $300 \mathrm{mg} / \mathrm{kg}[32,33,35]$.

In the regions with intensely developed husbandry, such as Belgorod oblast, organic fertilizers appear to be one of the main sources of microelement entrance to agrocenoses. As a rule, the concentration and ratio of different macro- and microelements varies significantly in organic fertilizers depending on the biological features, feeding ration and breeding technologies. Technological specifics of removal and storage of organic fertilizers affect these parameters significantly.

Introduction of $100 \mathrm{~kg} / \mathrm{ha}$ nitrogen requires straw and litter compost, cattle manure, and manure sewage in the dosage 3.3, 13.62 and $47.6 \mathrm{t} / \mathrm{ha}$, respectively; this amount of organics will add 525, 634, and $189 \mathrm{~g} / \mathrm{ha}$ of manganese; 990, 264, and $2537 \mathrm{~g} / \mathrm{ha}$ of zinc; and 597, 75, and $437 \mathrm{~g} / \mathrm{ha}$ of copper, respectively, to soil. Thus, upon introduction of similar dosage of nitrogen with the organic fertilizers, agrocenoses receive the highest amount of manganese, copper, and zinc with cattle manure, straw-litter compost, and manure sewage, respectively (Table 2 ). The most widespread mineral fertilizers contain very few microelements. According to our data, the average content of manganese, zinc, and copper is equal to 1.3, $0.68,0.37 \mathrm{mg} / \mathrm{kg}$ in ammonium nitrate; and it is equal to $72.4,11.8$, and $13.0 \mathrm{mg} / \mathrm{kg}$ in NPK fertilizer (16:16:16).

During 2015-2018, in Belgorod oblast, an average of $8.1 \mathrm{t} /$ ha organic fertilizers (recalculated for cattle manure), $0.5 \mathrm{t} /$ ha lime ameliorants (mainly defecate) and $112.3 \mathrm{~kg}$ a.s./ha $\left(\mathrm{N}_{75.1} \mathrm{P}_{20.6} \mathrm{~K}_{16.6}\right)$ of mineral fertilizers were introduced to the soil. An average of 389,162 , and $45.8 \mathrm{~g} / \mathrm{ha}$ of manganese, zinc, and copper, respectively, were introduced with organic fertilizers. The amount of manganese, zinc, and copper introduced with defecate was equal to $92.5 ; 21.9$; and $6.85 /$ ha, respectively. About $9.5 \mathrm{~g}$ of manganese, $1.65 \mathrm{~g}$ of zinc, and $1.74 \mathrm{~g}$ of copper were introduced on average with mineral fertilizers per 1 ha of the sown area. Taking into account the dosage of applied fertilizers and ameliorants, as well as the content of microelements in them, the total ingress of manganese, zinc, and copper constitutes $491,185.5$, and $54.4 \mathrm{~g}$ per 1 ha of the sown area. The ratio of manganese, zinc, and copper introduced with organic fertilizers was equal to 79.2, 87.3, and $84.2 \%$ of their total ingress to soil, respectively; $18.8,11.8$, and $12.6 \%$, with defecate; and 2.0, 0.9, and $3.2 \%$, with mineral fertilizers, respectively.

The content of microelements in soils. According to different data, the clarkes of manganese, zinc, and copper according to Kabata-Pedias [30] are 488, 70, and $38.9 \mathrm{mg} / \mathrm{kg}$, respectively, and 850,50 , and $20 \mathrm{mg} / \mathrm{kg}$, respectively, according to Vinogradov [1]; and 1000, 90 , and $30 \mathrm{mg} / \mathrm{kg}$, respectively, to Bowen [29]. The results of the study of chernozems in the Central Chernozem area proved that ordinary chernozem shows the 
maximal content of $\mathrm{Mn}, \mathrm{Zn}$, and $\mathrm{Cu}$ in the plow layer $(733,24$, and $71 \mathrm{mg} / \mathrm{kg}$, respectively). The content of $\mathrm{Mn}, \mathrm{Zn}$ and $\mathrm{Cu}$ rises in the row: leached chernozems < typical chernozems $<$ ordinary chernozems, which is due to the attenuating leaching processes and increasing biogenic accumulation of microelements in steppe chernozems [6].

In the layer of $10-20 \mathrm{~cm}$ of the virgin typical chernozem at the "Yamskaya steppe" site, "Belogor'e" Reserve, the background total content of manganese is 362 , of zinc, 44.7 , and copper $14.3 \mathrm{mg} / \mathrm{kg}$; these values are equal to $204,38.7$, and $11.5 \mathrm{mg} / \mathrm{kg}$, respectively, at the depth of $150-160 \mathrm{~cm}\left(\mathrm{C}_{\mathrm{Ca}}\right.$ horizon $)$. The total content of manganese, zinc, and copper is equal to $442,51.2$, and $18.6 \mathrm{mg} / \mathrm{kg}$, respectively, in the layer $15-25 \mathrm{~cm}$ of the virgin ordinary chernozem at "Roven'skii" National Park; and it is equal to 339, 49.6 and $16.5 \mathrm{mg} / \mathrm{kg}$ in the layer $110-120 \mathrm{~cm} \mathrm{[23].}$

In the $10-20 \mathrm{~cm}$ layer of typical chernozem at the "Yamskaya steppe" site, the content of mobile forms of manganese $(10.9 \mathrm{mg} / \mathrm{kg})$ and copper $(0.24 \mathrm{mg} / \mathrm{kg})$ is estimated as medium; and that of zinc $(0.79 \mathrm{mg} / \mathrm{kg})$ as low. In the layer $15-25 \mathrm{~cm}$ of ordinary chernozem in the "Roven'skii" National Park, the content of mobile forms of manganese is equal to 6.1, and that of zinc, $0.81 \mathrm{mg} / \mathrm{kg}$, which corresponds to a low supply level. The content of mobile copper $(0.2 \mathrm{mg} / \mathrm{kg})$ is at the medium level [23].

According to their total content in typical and ordinary chernozems, the elements form the following sequence: $\mathrm{Mn}>\mathrm{Zn}>\mathrm{Cu}$. The content of manganese, zinc, and copper is $1.15,1.18$, and 1.14 times higher in the A horizon of ordinary chernozem than in typical chernozem. This is explained by the heavier texture of ordinary chernozem (the physical clay content $72.5 \%$ ) as compared to typical chernozem (56.8\%).

The average total content of manganese, zinc, and copper in the Ap horizon of typical chernozem is higher than in the $\mathrm{C}$ horizon in 1.49, 1.17, and 1.22 times, respectively. A similar regularity is also typical for the ordinary chernozem, where the total content of manganese, zinc, and copper in the Ap horizon exceeds that in the $\mathrm{C}_{\mathrm{Ca}}$ horizon in $1.42,1.22$, and 1.16 times, respectively (Table 3 ).

The concentration of mobile compounds of the studied elements in soils shows a higher spatial variability as compared to their total content. The mobile forms of manganese, zinc, and copper in the Ap horizon compose $4.84,1.07$, and $0.65 \%$ of their total amount, respectively, in typical chernozem; and $1.03,0.84$, and $0.63 \%$ in ordinary chernozem.

In typical chernozem, the lowest content of mobile forms of manganese $(9.2 \mathrm{mg} / \mathrm{kg})$ was registered in the $\mathrm{AB}$ horizon; that of zinc $(0.26-0.29 \mathrm{mg} / \mathrm{kg})$, in $\mathrm{A}$ and $\mathrm{AB}$ horizons; and the copper content was minimal $(0.08-1.0 \mathrm{mg} / \mathrm{kg})$ in the Ap, $\mathrm{A}$, and $\mathrm{AB}$ horizons. The content of mobile forms of manganese and copper in the $\mathrm{BC}_{\mathrm{Ca}}$ and $\mathrm{C}_{\mathrm{Ca}}$ horizons was reliably higher than in the Ap horizon. No reliable difference was revealed between the content of mobile zinc in the $\mathrm{Ap}, \mathrm{BC}_{\mathrm{Ca}}$ and $\mathrm{C}_{\mathrm{Ca}}$ horizons.

In the Ap horizon of ordinary chernozem, the content of mobile forms of manganese averaged to $4.1 \mathrm{mg} / \mathrm{kg}$, which is significantly lower than in typical chernozem $(16.7 \mathrm{mg} / \mathrm{kg})$. In the same horizon, no reliable difference was revealed for the content of mobile forms of zinc and copper between the ordinary and typical chernozem. The content of mobile forms of manganese, zinc and copper was reliably higher in the $\mathrm{C}_{\mathrm{Ca}}$ horizon than in the Ap horizon.

In leached chernozems, which are characterized by weakly acid reaction, the content of mobile forms of microelements is usually higher in the Ap horizon than in the $\mathrm{AB}$ horizon (the alkaline barrier) [26]. However, in the strongly alkaline medium (the $\mathrm{BC}_{\mathrm{Ca}}$ and $\mathrm{C}_{\mathrm{Ca}}$ horizons), the mobility of elements with amphoteric properties may increase [11, 19].

The results of the tenth cycle (2015-2018) of the continuous agrochemical monitoring showed that $38.6,98.7$, and $98.2 \%$ of arable soils are referred to the group of low supply by mobile manganese, zinc, and copper, respectively. Introduction of microfertilizers appears to be efficient in these soils. The weighted average content of mobile manganese, zinc, and copper in the local soils is equal to $11.7,0.5$, and $0.11 \mathrm{mg} / \mathrm{kg}$, respectively (Table 4). No excess over MPC and APC of mobile forms of the studied microelements was registered in the area in the course of observations. During the ninth observation cycle (2010-2014), the weighted average content of manganese mobile forms was lower $(10.3 \mathrm{mg} / \mathrm{kg})$; that of zinc, somewhat higher $(0.52 \mathrm{mg} / \mathrm{kg})$; and that of copper was stable $(0.11 \mathrm{mg} / \mathrm{kg})$.

A close correlation $(r=0.72)$ was revealed between the weighted average value of soil, hydrolytic acidity and the content of mobile zinc in soil profiles of administrative regions of the Belgorod oblast; and the medium correlation was found between the content of mobile copper $(r=0.33)$ and manganese $(r=0.34)$. Medium correlation $(r=0.54)$ was also registered between the content of organic matter and of mobile cobalt. At the same time, no correlation was found between the organic matter content and the concentration of mobile zinc and manganese.

A deficit in mobile forms of microelements is observed in arable soils in many regions of Russia. For example, the share of soils poorly supplied with mobile forms of manganese, zinc and copper is equal to $95.4,97.9$ and $100 \%$ in Tambov oblast, and 61.9, 99.7, and 96.5\% in Voronezh oblast [10, 28].

Content of microelements in plants. The content of microelements in plants is controlled in many respects by the chemical composition of the environment, in which the given plant species has been formed.

Manganese content in plants usually ranges within $20-300 \mathrm{mg} / \mathrm{kg}$ in dry matter $[7,20]$. In the average it 


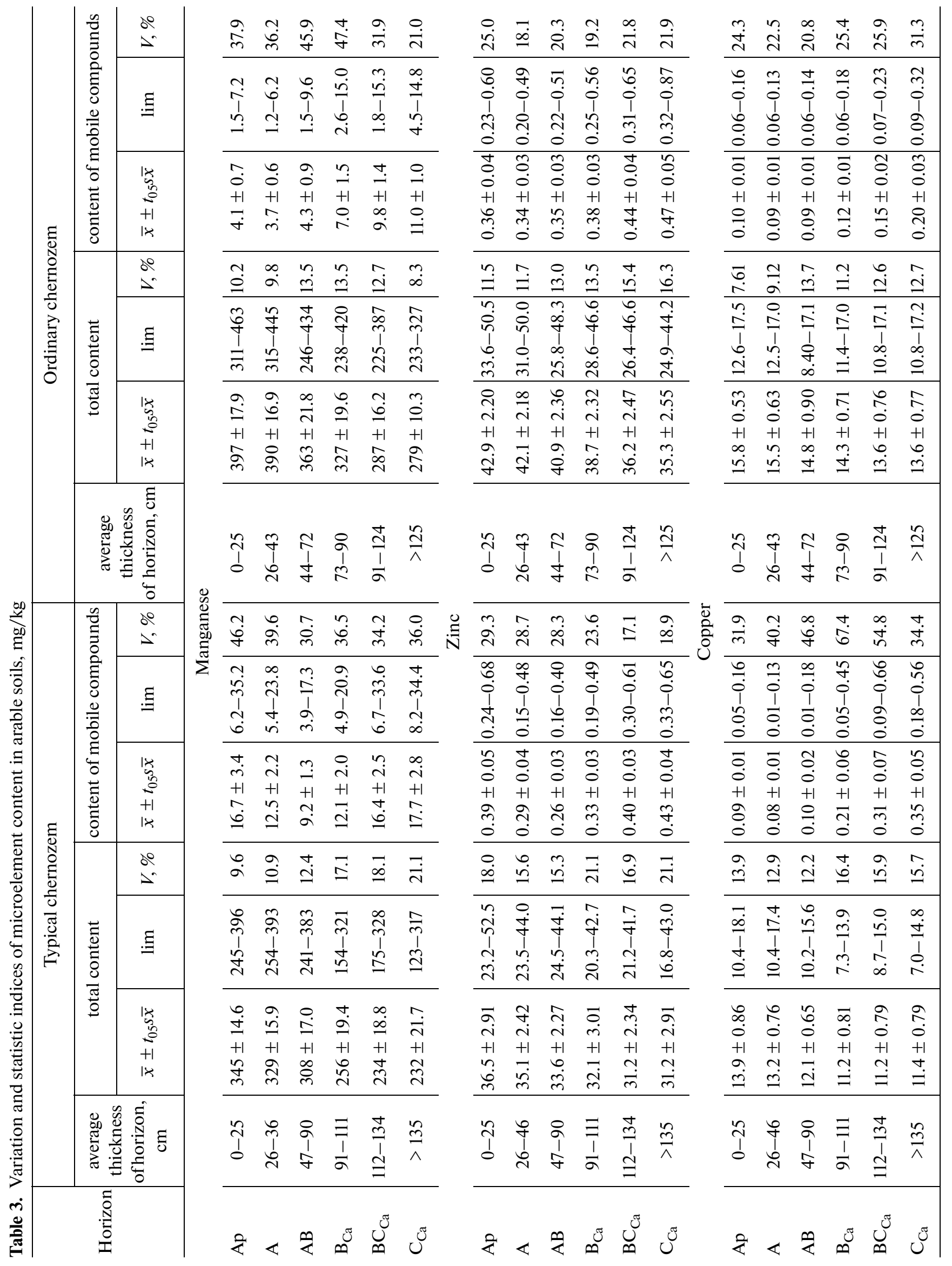




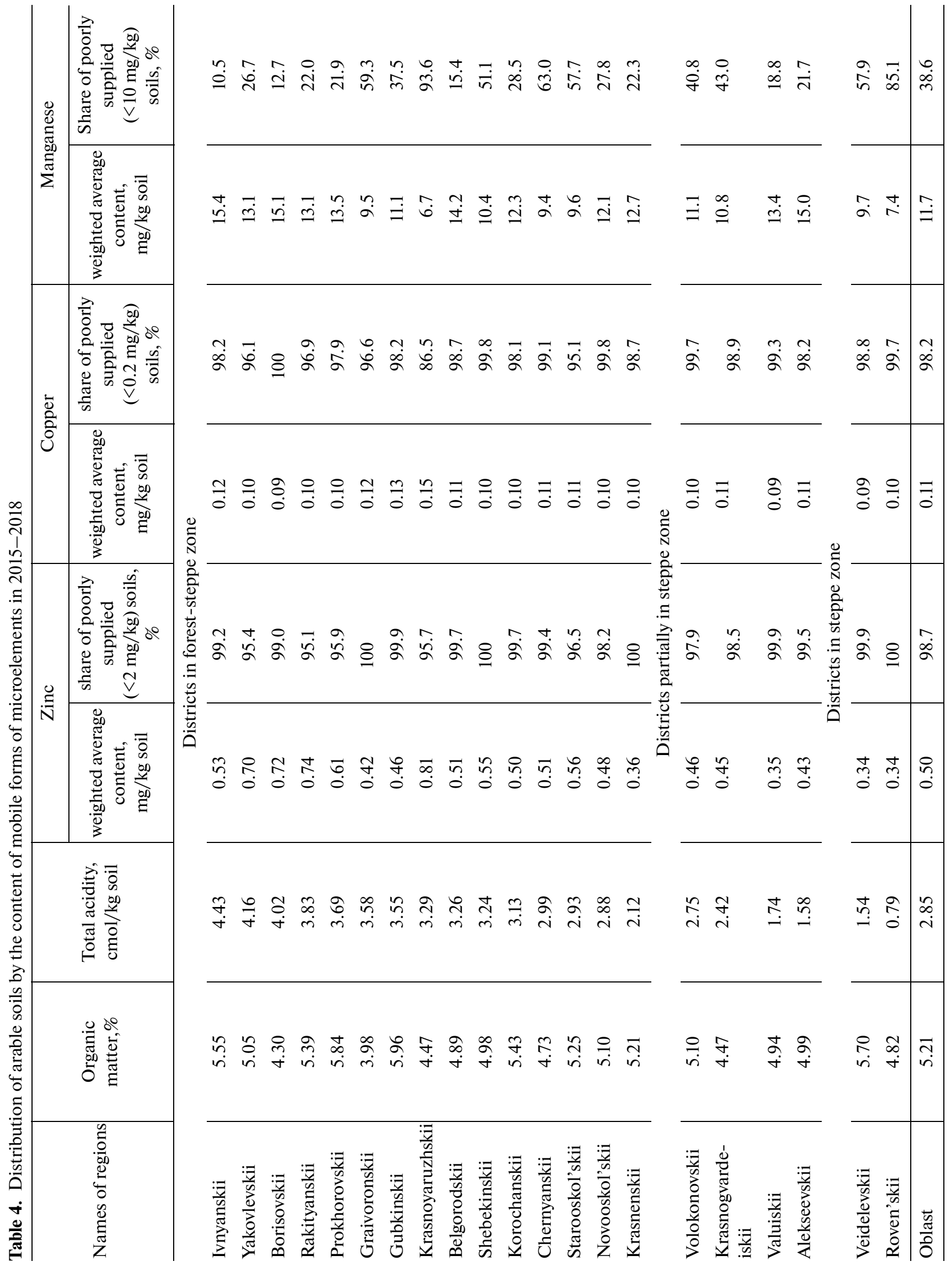


Table 5. Variation and statistic indices of microelement content in crop production

\begin{tabular}{l|l|c|c|c|c|c|c|c|c|c}
\hline \multirow{2}{*}{\multicolumn{2}{c|}{ Crop }} & \multicolumn{3}{c|}{ Manganese } & \multicolumn{3}{c|}{ Zinc } & \multicolumn{3}{c}{ Copper } \\
\cline { 3 - 11 } \multicolumn{2}{l|}{} & $\bar{x} \pm t_{05} s \bar{x}$ & $\lim$ & $V, \%$ & $\bar{x} \pm t_{05} s \bar{x}$ & $\lim$ & $V, \%$ & $\bar{x} \pm t_{05} s \bar{x}$ & $\lim$ & $V, \%$ \\
\hline \multirow{2}{*}{ Winter wheat } & Grain & $33.3 \pm 2.79$ & $23.0-48.1$ & 18.9 & $28.6 \pm 1.55$ & $26.4-34.0$ & 11.6 & $3.60 \pm 0.33$ & $2.17-5.18$ & 20.9 \\
\multirow{4}{*}{ White lupine } & Straw & $23.7 \pm 1.99$ & $15.3-30.9$ & 19.0 & $10.4 \pm 0.69$ & $8.55-13.7$ & 14.1 & $1.98 \pm 0.20$ & $1.30-2.70$ & 22.9 \\
& Grain & $1053 \pm 50.9$ & $857-1221$ & 10.3 & $43.5 \pm 1.91$ & $36.5-51.1$ & 9.4 & $5.94 \pm 0.58$ & $3.79-7.76$ & 20.7 \\
Soybean & Straw & $841 \pm 91.2$ & $594-1207$ & 23.2 & $8.98 \pm 1.20$ & $6.10-16.21$ & 28.5 & $1.94 \pm 0.13$ & $1.39-2.58$ & 14.6 \\
& Grain & $24.1 \pm 1.15$ & $16.9-27.9$ & 10.8 & $35.6 \pm 3.54$ & $25.3-47.3$ & 22.5 & $10.5 \pm 1.58$ & $5.12-16.7$ & 33.8 \\
Pea & Straw & $12.4 \pm 1.10$ & $7.50-17.6$ & 20.0 & $6.38 \pm 0.59$ & $4.49-8.54$ & 20.7 & $3.53 \pm 0.48$ & $1.73-5.24$ & 31.0 \\
& Grain & $9.22 \pm 0.47$ & $7.33-10.9$ & 11.6 & $26.45 \pm 1.47$ & $17.34-30.9$ & 12.6 & $3.85 \pm 0.33$ & $1.88-4.79$ & 19.6 \\
Clover & Straw & $18.0 \pm 1.67$ & $7.76-22.5$ & 21.0 & $3.34 \pm 0.57$ & $1.30-5.51$ & 38.5 & $2.55 \pm 0.31$ & $1.09-4.00$ & 27.5 \\
sainfoin & Hay & $31.2 \pm 1.69$ & $24.5-37.6$ & 12.3 & $16.5 \pm 0.81$ & $13.0-19.2$ & 11.0 & $3.22 \pm 0.22$ & $2.49-4.29$ & 15.3 \\
alfalfa & Hay & $30.7 \pm 0.97$ & $27.4-34.9$ & 7.1 & $17.8 \pm 1.0$ & $12.7-20.7$ & 12.7 & $4.12 \pm 0.54$ & $2.21-5.85$ & 29.7 \\
Steppe mixed & Hay & $28.5 \pm 1.48$ & $22.9-37.5$ & 11.8 & $14.0 \pm 1.82$ & $6.88-19.8$ & 29.3 & $5.61 \pm 0.53$ & $3.56-7.47$ & 21.3 \\
herbs & Hay & $41.2 \pm 2.97$ & $31.6-53.9$ & 16.3 & $21.7 \pm 1.23$ & $16.3-26.3$ & 12.8 & $4.24 \pm 0.34$ & $3.30-5.98$ & 18.0 \\
\hline
\end{tabular}

was equal to $41.2 \mathrm{mg} / \mathrm{kg}$ in steppe forbs at the "Yamskaya Steppe" reserve plot. According to our studies, white lupine is very capable to accumulate this element. The average content of manganese was equal to $1053 \mathrm{mg} / \mathrm{kg}$ in this crop grain; and it was equal to $841 \mathrm{mg} / \mathrm{kg}$ in its straw. For comparison, in the grain of winter wheat, soybean, and pea, the content of this element was by 31.6, 43.7 and 114.2 times lower, and amounted to $33.3,24.3$, and $9.22 \mathrm{mg} / \mathrm{kg}$, respectively. In the area of white lupine origin (Mediterranean countries), the soils most probably were characterized by a very high content of plant-available manganese, which favored its accumulation in plants and fixation of this feature in the course of evolution. Plants of winter wheat, white lupine and soybean contained by $1.41,1.25$, and 1.94 times more this element, respectively, in their principal products than in byproducts. Manganese content was 1.95 times higher in the pea straw than in grain. The average content of manganese was rather close in the hay of alfalfa $(28.5 \mathrm{mg} / \mathrm{kg})$, sainfoins $(30.7 \mathrm{mg} / \mathrm{kg})$, and clover $(31.2 \mathrm{mg} / \mathrm{kg})$ (Table 5).

According to the published data, the content of zinc in plants is equal to $20-60 \mathrm{mg} / \mathrm{kg}$; whereas the toxic concentrations decreasing the crop yield constitute $300-500 \mathrm{mg} / \mathrm{kg}[8,26]$. The content of this element averaged to $21.7 \mathrm{mg} / \mathrm{kg}$ in the steppe forbs in the reserve area. Grains of white lupine and soybean showed the highest zinc content $(43.5$ and $35.6 \mathrm{mg} / \mathrm{kg}$, respectively). The content of this element did not differ reliably in grains of winter wheat $(28.6 \mathrm{mg} / \mathrm{kg})$ and pea. The main products of winter wheat, white lupine, soybean and pea contained by $2.75,4.84,5.58$, and 7.92 times more zinc than byproducts, which points to a significant role of this microelement in the development of reproductive organs of plants. Zinc content in sainfoins, clover and alfalfa hay constituted 17.8, 16.5, and $14.0 \mathrm{mg} / \mathrm{kg}$, on average, respectively.

Copper content usually varies in plants within 1.0$30.0 \mathrm{mg} / \mathrm{kg}$ [16]. This element is not reutilized in plants [27]. In steppe forbs, the copper concentration averages to $4.24 \mathrm{mg} / \mathrm{kg}$. The highest copper concentration was found in soybean $(10.5 \mathrm{mg} / \mathrm{kg})$ and white lupine $(5.94 \mathrm{mg} / \mathrm{kg})$ grains. It is significantly lower in grains of winter wheat $(3.60 \mathrm{mg} / \mathrm{kg})$ and pea $(3.85 \mathrm{mg} / \mathrm{kg})$. The copper content was $1.82,3.06,2.97$ and 1.51 times higher in grain than in straw of winter wheat, white lupine, soybean, and pea, respectively. Among perennial legumes, alfalfa manifests the highest copper amount $(5.61 \mathrm{mg} / \mathrm{kg})$ and clover, the lowest $(3.22 \mathrm{mg} / \mathrm{kg})$. No excess over maximal permissible level (MPL) in forage products were revealed in the course of studies for zinc and copper.

The biological absorption coefficient (BAC) is used for assessing the selectivity of microelement consumption by plants from the soil. As a rule, all the studied microelements showed BAC $>1$ (Table 6). Therefore, according to Perel'man classification, these microelements are referred to the group of strong and intense accumulation, characterized by biophilic accumulation in the soil arable layer $[15,16]$. Since chernozems were formed under steppe vegetation, the BAC value for microelements by steppe forbs controls in many respects the regularities of their distribution by the soil profile depth. According to their BAC by steppe forbs, the elements form the following sequence: $\mathrm{Zn}(7.59)>\mathrm{Cu}$ (4.46) > Mn (1.78).

Among agricultural plants, white lupine manifested the highest BAC for manganese (72.67 and 39.32 in grain and straw, respectively), whereas pea had the lowest (0.86 and 0.65 in grain and straw, 
Table 6. Content of microelements in plant ash and biological absorption coefficients (mg $/ \mathrm{kg}$ ash) $/(\mathrm{mg} / \mathrm{kg} \mathrm{soil)}$

\begin{tabular}{|c|c|c|c|c|c|c|c|c|}
\hline \multirow{2}{*}{\multicolumn{2}{|c|}{ Crop }} & \multirow{3}{*}{$\begin{array}{c}\text { Ash content, } \% \\
\text { of absolutely dry matter } \\
2.2\end{array}$} & \multicolumn{2}{|c|}{ Manganese } & \multicolumn{2}{|c|}{ Zinc } & \multicolumn{2}{|c|}{ Copper } \\
\hline & & & \multirow{2}{*}{$\begin{array}{c}\mathrm{mg} / \mathrm{kg} \text { ash } \\
1514\end{array}$} & \multirow{2}{*}{$\begin{array}{r}\text { BAC } \\
4.39\end{array}$} & \multirow{2}{*}{$\frac{\mathrm{mg} / \mathrm{kg} \text { ash }}{1300}$} & \multirow{2}{*}{$\begin{array}{l}\text { BAC } \\
35.62\end{array}$} & \multirow{2}{*}{$\frac{\mathrm{mg} / \mathrm{kg} \text { ash }}{163.6}$} & \multirow{2}{*}{$\begin{array}{l}\text { BAC } \\
11.77\end{array}$} \\
\hline Winter wheat & Grain & & & & & & & \\
\hline & Straw & 6.9 & 343.5 & 1.00 & 150.7 & 4.13 & 28.7 & 2.06 \\
\hline \multirow[t]{2}{*}{ White lupine } & Grain & 4.2 & 25071 & 72.67 & 1036 & 28.38 & 141.4 & 10.17 \\
\hline & Straw & 6.2 & 13565 & 39.32 & 144.8 & 3.97 & 31.3 & 2.25 \\
\hline \multirow[t]{2}{*}{ Soybean } & Grain & 5.2 & 463.5 & 1.34 & 684.6 & 18.76 & 201.9 & 14.53 \\
\hline & Straw & 5.6 & 221.4 & 0.64 & 113.9 & 3.12 & 63.0 & 4.53 \\
\hline \multirow[t]{2}{*}{ Pea } & Grain & 3.1 & 297.4 & 0.86 & 853.2 & 23.38 & 124.2 & 8.94 \\
\hline & Straw & 8.0 & 225.0 & 0.65 & 41.8 & 1.15 & 31.9 & 2.29 \\
\hline Clover & Hay & 8.5 & 367.1 & 1.06 & 194.1 & 5.32 & 37.9 & 2.73 \\
\hline Sainfoins & Hay & 5.6 & 548.2 & 1.59 & 317.9 & 8.71 & 73.6 & 5.29 \\
\hline Alfalfa & Hay & 8.8 & 323.9 & 0.94 & 159.1 & 4.36 & 63.8 & 4.59 \\
\hline Steppe mixed herbs & Hay & 6.4 & 643.8 & 1.78 & 339.1 & 7.59 & 66.3 & 4.64 \\
\hline
\end{tabular}

respectively). BAC of this element was relatively low for sainfoins (1.59), clover (1.06) and alfalfa (0.94).

Zinc was maximally absorbed by winter wheat, with BAC value registered as 35.62 for grain and 4.13 for straw. For this element, the lowest BAC was registered in pea straw (1.15). According to BAC, perennial legumes form he following sequence: sainfoins (8.71) > clover (5.32) and alfalfa (4.36).

For copper, the highest BAC was registered for soybean plants (14.53, in grain, and 4.53, in straw), and the lowest, was found for pea (8.94, in grain, and 2.29, in straw). Among leguminous herbs, the highest value of this parameter was registered for sainfoins (5.29), and the lowest one, for clover (2.73).

\section{CONCLUSIONS}

Organic fertilizers were found to be the main source of microelements coming to agrocenoses in Belgorod oblast in 2015-2018. They were responsible for $79.2 \%$ manganese, $87.3 \%$ zinc, and $84.2 \%$ copper of the total amount of elements introduced with fertilizers and ameliorants.

The Ap horizon of ordinary chernozem contained $1.15,1.18$, and 1.14 times more manganese, zinc, and copper, respectively, than typical chernozem. Biophilic accumulation in the arable layer is typical for the studied elements. The average total content of manganese, zinc, and copper in the Ap horizon was 1.49, 1.17 , and 1.22 times higher than in $\mathrm{C}_{\mathrm{Ca}}$ horizon, respectively, for typical chernozem; and 1.42, 1.22, and 1.16 times, for ordinary chernozem. The continuous monitoring results proved that $38.5,98.7$ and $98.2 \%$ of studied arable soils showed a low supply with mobile manganese, zinc, and copper, respectively. A close correlation $(r=0.72)$ is registered among the weighted average value of soil hydrolytic acidity and the mobile zinc content; whereas medium correlation is found for the content of mobile copper $(r=0.33)$ and manganese $(r=0.34)$.

The highest total content of manganese was registered in grain $(1053 \mathrm{mg} / \mathrm{kg})$ and straw $(841 \mathrm{mg} / \mathrm{kg})$ of white lupine; zinc, in the same crop grain $(43.5 \mathrm{mg} / \mathrm{kg})$, and copper, in soybean grain $(10.5 \mathrm{mg} / \mathrm{kg})$. The lowest accumulation of manganese $(9.22 \mathrm{mg} / \mathrm{kg})$ and zinc $(26.45 \mathrm{mg} / \mathrm{kg})$ was typical for pea grain, and that of copper, for winter wheat grain $(3.60 \mathrm{mg} / \mathrm{kg})$. The concentration of microelements was higher in grain than in straw of winter wheat, soybean, and white lupine; whereas the reverse dependence is found for pea plants. According to their BAC values for steppe forbs, the elements form the following sequence: $\mathrm{Zn}(7.59)>$ $\mathrm{Cu}$ (4.46) > Mn (1.78).

\section{CONFLICT OF INTEREST}

The authors declare that they have no conflict of interest.

\section{REFERENCES}

1. A. P. Vinogradov, Geochemistry of Rare and Scattered Chemical Elements in Soils (Academy of Sciences of the USSR, Moscow, 1957) [in Russian].

2. VMDU-87: Temporal Maximum Permissible Concentrations of Some Chemical Elements and Gossypol in Fodders and Food Additives for Livestock (Moscow, 1987) [in Russian].

3. Yu. N. Vodyanitskii, "Zinc forms in soils (review of publications)," Eurasian Soil Sci. 43, 269-277 (2010).

4. GN 2.1.7.2041-06: Maximum Permissible Concentrations (MPCs) of Chemical Substances in Soil (Moscow, 2006) [in Russian].

5. GN 2.1.7.2511-09: Tentative Permissible Concentrations (TPCs) of Chemical Substances in Soil (Moscow, 2009) [in Russian]. 
6. N. S. Gorbunova and N. A. Protasova, "Forms of manganese, copper and zinc compounds of in chernozems of the central chernozemic region," Vestn. Voronezh. Gos. Univ., Ser. Khim., Biol., Farm., No. 2, 77-85 (2008).

7. P. O. Duglas, "Impact of trace element pollution on the plants?" in Aerial Pollution and Life of the Plants (Gidrometeoizdat, Leningrad, 1988), pp. 327-356.

8. I. I. Igonov and I. F. Kargin, "Content dynamics of heavy metals during prolonged use of arable lands," Agrokhim. Vestn., No. 4, 35-37 (2012).

9. V. I. Kiryushin, "The management of soil fertility and productivity of agrocenoses in adaptive-landscape farming systems," Eurasian Soil Sci. 52, 1137-1145 (2019).

10. V. I. Korchagin, Candidate's Dissertation in Agriculture (Voronezh, 2017).

11. Yu. A. Mazhaiskii, "Specific distribution of heavy metals within the soil profiles in Ryazan oblast," Agrokhimiya, No. 8, 74-79 (2003).

12. I. F. Medvedev and S. S. Derevyagin, Heavy Metals in Ecosystems (Rakurs, Saratov, 2017) [in Russian].

13. Practical Guide for Analysis of Heavy Metals in Agricultural Soils and Vegetable Products (Timiryazev Moscow Agricultural Academy, Moscow, 1992) [in Russian].

14. M. G. Opekunova, A. Yu. Opekunov, S. Yu. Kukushkin, and A. G. Ganul, "Background contents of heavy metals in soils and bottom sediments in the north of Western Siberia,” Eurasian Soil Sci. 52, 380-395 (2019).

15. D. S. Orlov, L. K. Sadovnikova, and I. N. Lozanovskaya, Ecology and Protection of Soils of the Biosphere under Chemical Pollution (Vysshaya Shkola, Moscow, 2002) [in Russian].

16. A. I. Perel'man, Geochemistry of a Landscape (Vysshaya Shkola, Moscow, 1975) [in Russian].

17. A. S. Poddubnyi, "Dynamics of agrochemical conditions of arable soils in forest-steppe of Belgorod oblast," Dostizh. Nauki Tekh. APK 32 (6), 15-17 (2018).

18. V. V. Popov, "Fertility of arable lands in the southeastern regions of Rostov oblast," Dostizh. Nauki Tekh. APK 32 (3), 7-11 (2018).

19. N. A. Protasova and A. P. Shcherbakov, Trace Elements (Cr, V, Ni, Mn, Zn, Cu, Co, Ti, Zr, Ga, Be, Sr, Ba, B, I, Mo) in Chernozems and Gray Forest Soils of Central Chernozemic Region (Voronezh State University, Voronezh, 2003) [in Russian].

20. A. V. Puzanov and S. S. Meshkinova, "Trace elements in the plants of the Srednyaya Katun valley," Vestn. Altaisk. Gos. Agrar. Univ., No. 12 (62), 47-54 (2009).

21. Russian Regions: Social-Economic Indices, Statistical Handbook (Moscow, 2018) [in Russian]. https://www.gks.ru/ free_doc/doc_2018/region/reg-pok18.pdf.

22. SanPiN 2.3.2.1078-01: Hygienic Requirements to Safety and Nutritional Value of Food (Moscow, 2001) [in Russian].
23. V. D. Solovichenko, S. V. Lukin, F. N. Lisetskii, and P. V. Goleusov, The Red Data Book of Soils of Belgorod Oblast (Belgorod State University, Belgorod, 2007) [in Russian].

24. V. D. Solovichenko and S. I. Tyutyunov, Soil Cover of Belgorod Oblast and Its Rational Use (Otchii Krai, Belgorod, 2013) [in Russian].

25. O. A. Sukhova, V. V. Boldyrev, and A. V. Akulov, "Monitoring of trace elements content in soils of Volgograd oblast," Dostizh. Nauki Tekh. APK 33 (4), 2021 (2019).

26. R. M. Khizhnyak, Candidate's Dissertation in Biology (Moscow, 2016).

27. A. Kh. Sheudzhen, Biogeochemistry (Adygeya, Maikop, 2003) [in Russian].

28. N. P. Yumashev and I. A. Trunov, Soils of Tambov Oblast (Michurinsk State Agrarian University, Michurinsk, 2006) [in Russian].

29. H. J. M. Bowen, Environmental Chemistry of the Elements (Academic, London, 1979).

30. A. Kabata-Pendias, Trace Elements in Soils and Plants, 4th ed. (CRC Press, Boca Raton, FL, 2011).

31. R. M. McKenzie, I. M. Varentsov, and G. Grasselly, "The manganese oxides in soils," in Geology and Geochemistry of Manganese (Akademiai Kiado, Budapest, 1980).

32. B. T. Pavilonis, P. J. Lioy, S. Guazzetti, B. C. Bostick, F. Donna, M. Peli, P. G. Georgopoulos, and R. G. Lucchini, "Manganese concentrations in soil and settled dust in an area with historic ferroalloy production," J. Exposure Sci. Environ. Epidemiol. 25 (4), 443-450 (2014). https://doi.org/10.1038/jes.2014.70

33. I. Timofeev, N. Kosheleva, and N. Kasimov, "Contamination of soils by potentially toxic elements in the impact zone of tungsten molybdenum ore mine in the Baikal region: a survey and risk assessment," Sci. Total Environ. 642, 63-76 (2018). https://doi.org/10.1016/j.scitotenv.2018.06.042

34. E. van der Voet, R. Salminen, M. Eckelman, G. Mudd, T. Norgate, and R. Hischier, Environmental Risks and Challenges of Anthropogenic Metals Flows and Cycles (UN International Resource Panel, Nairobi, 2013).

35. R. Xiao, A. Ali, P. Wang, R. Li, X. Tian, and Z. Zhang, "Comparison of the feasibility of different washing solutions for combined soil washing and phytoremediation for the detoxification of cadmium $(\mathrm{Cd})$ and zinc (Zn) in contaminated soil," Chemosphere 230, 510518 (2019). https://doi.org/10.1016/j.chemosphere.2019.05.121

Translated by $O$. Eremina 